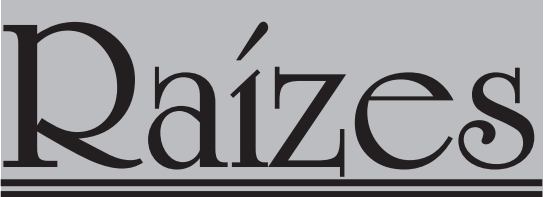

v.33, n.2, jul-dez /2013

\title{
O DISCURSO OCULTO DOS RETIRANTES DAS SECAS
}

\section{Frederico de Castro Neves}

\begin{abstract}
RESUMO
Este artigo examina algumas possibilidades de entendimento das ações de camponeses pobres no nordeste brasileiro, durante as secas, a partir do conceito de discurso oculto, central na obra de James C. Scott. Assim, três situações são privilegiadas: a relação com o Imperador D. Pedro II, nos anos finais do Império; o discurso das lideranças e as relações entre camponeses e trabalhadores urbanos; e a observação de um projeto geral de sociedade ideal que orienta as ações dos retirantes.
\end{abstract}

Palavras-chave: Camponeses; Discurso Oculto; Ações das Multidões.

\section{THE HIDDEN TRANSCRIPTS OF DROUGHTS MIGRANTS}

\begin{abstract}
This article examines some possibilities for understanding the actions of poor farmers in northeast Brazil, during droughts, from the concept of hidden transcripts, central in the work of James C. Scott. Thus, three scenarios are privileged: the relationship with the Emperor D. Pedro II, in the final years of the Empire; the discourse of leadership and relations between peasants and urban workers; and the observation of an overall project of an ideal society that guides the actions of the migrant peasants.
\end{abstract}

Key words: Peasants; Hidden Transcripts; Crowds Movements

Doutor em História Social. Professor do Departamento de História da Universidade Federal do Ceará. E-mail: fredcneves@msn.com. 
INTRODUÇÃO

Este artigo foi obviamente inspirado pela leitura da versão em português do livro de James C. Scott, A Dominação e a Arte da Resistência: Discursos Ocultos, editado, em 2013, pela Livraria Letra Livre, de Lisboa. Esta não foi, contudo, a minha primeira leitura deste prestigiado autor norte-americano, cujas inclinações libertárias são evidentes e notórias. Devo a Sidney Chalhoub a indicação de seus livros, quando, no momento da defesa de minha tese de doutorado, em 1998, alertou para as semelhanças e correspondências entre meus resultados de pesquisa e as abordagens de Scott, especialmente em Weapons of the Weak: Everyday Forms of Peasant Resistence, de 1985. ${ }^{1}$

O período compreendido entre a defesa da tese e a publicação do livro que se lhe seguiu (2000) foi, para mim, de intensa leitura de todos os textos de Scott que podia encontrar, avaliando que sua percepção sobre as formas de resistência cotidiana dos pobres, sobre o discurso oculto dos dominados e sobre a presença ubíqua de uma justiça popular muitas vezes opaca em relação à justiça oficial podia ser útil para a compreensão dos atos das multidões de camponeses que se transformam em retirantes durante os períodos de seca no semiárido brasileiro. Por isso, olhando retrospectivamente, o livro parece atravessado por possibilidades de interpretações pouco desenvolvidas, por sugestões conceituais mal formuladas e por conclusões pela metade. Tentei remendar o pano por diversas vezes nos anos posteriores, mas cedo percebi que isso não tinha sentido lógico. $\mathrm{O}$ que tinha sido escrito em 1997 (defendido como tese de doutorado no início de 1998 e publicado quase integralmente no ano 2000) era o resultado de um conjunto de reflexões dos anos anteriores e só poderia ser o que foi. A questão que se colocava então era: como retomar as temáticas de pesquisa que vinha desenvolvendo desde o começo dos anos de 1990 à luz das inquietações trazidas pelos livros de Scott, incorporando-as às outras inquietações advindas de outras leituras igualmente poderosas. Isso eu poderia fazer.

O centro temático dessas pesquisas é o conjunto de ações desempenhadas por camponeses do semiárido brasileiro que podem ser enquadradas como "invasões", "saques" ou "ameaças", que ocorrem a partir de $1877 \mathrm{em}$ momentos específicos de escassez generalizada, conhecidos como "secas". Parti do princípio de que as ciências sociais estavam, de maneira geral, contaminadas por aquilo que Thompson chamou de "visão espasmódica", isto é, uma abordagem que despolitiza os populares ao circunscrever suas ações ao universo dos instintos de sobrevivência, associando-as à fome e à destruição das condições básicas de vida. (Neves, 2000, p. 15-20; Thompson, 1998, p. 150202) Pensei sempre as ações das multidões, ao contrário, como opções construídas a partir de uma cultura política sertaneja e popular, que oferece aos seus membros um arsenal de possibilidades políticas que podem ou não ser acionadas pelos camponeses, dependendo do contexto social.

A "resistência" praticada pelos camponeses, portanto, se reveste de novas e variadas

1 Outra indicação de Chalhoub, igualmente frutífera, foi à leitura dos textos que se incluem sob a rubrica genérica de Subaltern Studies, grupo de historiadores indianos cuja referência mais importante é Ranajit Guha (Elementary Aspects of Peasant Insurgency, 1983). 
formas no contexto da modernização agrícola e na formação de novas obrigações para com os proprietários das terras e para com o Estado, durante o processo de consolidação da República no Brasil. Este tema é igualmente importante para Scott, cujo The Moral Economy of the Peasant (1976) trata de processos de resistência desenvolvido por camponeses malaios em contextos socioeconômicos semelhantes. Deste livro, a analogia com os recifes de corais, formados por milhões de pequenos indivíduos, cuja presença somente é notada quando um grande navio se choca contra essa barreira natural, foi-me particularmente preciosa para perceber a resistência cotidiana, baseada em uma suposta estupidez, praticada pelos camponeses que se inseriam (ou eram inseridos) em programas de modernização agrícola no nordeste brasileiro. Parece claro para mim, agora, que esses programas falharam por decisão coletiva dos camponeses, que se recusaram a implementar medidas que alteravam suas culturas tradicionais, direcionando-as para o mercado. Com isso, o processo de mercantilização da agricultura esbarrou em obstáculos para os quais ainda não se encontrou solução e o chamado "agronegócio" fica restrito a determinadas ilhas de produção de mercadorias, para onde, infelizmente, é dirigido o fluxo estatal de investimentos para infraestrutura. Grande parte do semiárido nordestino é dominado pela agricultura de subsistência, com base na economia familiar da pequena produção, com inserção parcial nos mercados locais, cuja vulnerabilidade às variações das forças de produção é constatada pelas migrações contínuas e pelas secas periódicas.

Essa decisão coletiva precisa ainda ser compreendida em seus aspectos microscópicos e micro-históricos, mas pode servir de referên- cia para outras abordagens igualmente interessantes, que insistem no protagonismo dos camponeses e dos pobres rurais e urbanos no processo de formação da sociedade moderna, da qual eles parecem "excluídos".

Outros aspectos certamente podem ser sugeridos pela leitura de Scott. Para fins desse artigo, portanto, selecionei três elementos cujas análises podem ser iluminadas pela noção de "discurso oculto".

\section{O POVO E O IMPERADOR}

Scott chama de "monarquismo ingênuo" práticas populares de reverência e consentimento que são colocadas em ação por camponeses na relação que estabelecem com reis e príncipes, e que se estendem, muitas vezes, aos governantes em geral. O exemplo mais destacado é o da Rússia, onde os czares extraem uma boa parte de sua legitimidade social desse sentimento de proteção e vigilância que os pobres entendem ser prerrogativa do governante. Por meio desse "mito", as mazelas sociais e os desmandos governamentais podem ser atribuídos a prepostos e outros intermediários da ordem estatal, mantendo o rei afastado dos conflitos sociais e protegido por uma aura de consentimento popular. Os descontentamentos do povo são, assim, canalizados em direção e esses funcionários medianos, os quais, uma vez desmascarados, seriam punidos pelo governante piedoso e incorruptível. Contudo, "talvez o aspecto mais notável desse mito fosse a sua flexibilidade às mãos dos camponeses que o abraçavam". Com base neste mesmo mito, os camponeses conseguem pressionar autoridades locais e realizar façanhas consideráveis na luta contra 
a expropriação de suas terras, a imposição de um sobre-trabalho e o incremento de novos impostos. Jogando com os estereótipos definidos pelo mito do monarquismo ingênuo ("camponês ingênuo, czar benevolente”), os pobres invertem, em contextos específicos, os significados conferidos ao processo de distribuição da riqueza social ou de apropriação de bens pelo Estado. (Scott, 2013, p. 145-150).

No Brasil imperial, uma boa parte dos investimentos simbólicos realizados pelo Estado dirigiu-se à consolidação de uma imagem positiva do Imperador. Assim como homem culto segundo os padrões mais exigentes da cultura europeia, ele deveria aparecer publicamente, aos olhos da população, como um homem benevolente e caridoso, protetor dos pobres e necessitados. Um amplo arco de pertencimento englobaria os desvalidos sob a proteção imperial apresentando D. Pedro II como o 'pai dos pobres'. A conexão com a Igreja Católica garantia a abrangência nacional e o empenho institucional para a efetivação de um paternalismo baseado na caridade e na esmola.

Uma crise econômica, política e social de dimensões nacionais, como a seca de 1877 1880 , poderia colocar em risco toda a montagem dessa estrutura simbólica que configura o Imperador como o "papai Pedro", o "nosso imperador véio", conforme narrativas de $1915 .^{2}$ Contudo, o gigantesco sistema de socorros implementado em 1878 - assegurando assistência, ao custo do trabalho árduo e mal remunerado, a centenas de milhares de camponeses - confe- riu uma base de realidade a um rumor amplamente difundido, de que o Imperador 'venderia até a última joia da Coroa, mas não permitiria que um cearense morresse de fome'.

De fato, o sistema de socorros públicos foi colocado em prática pelos liberais, adversários de D. Pedro II, que o usaram como arma para desarticular a assistência estatal baseada nas esmolas. O trabalho nas obras públicas transformou-se em princípio básico de assistência aos retirantes das secas, absorvendo uma população desvalida e enfraquecida, cujo esforço até a morte foi empregado na construção de uma infraestrutura para o 'progresso'. Por outro lado, não há registros de que o Imperador tenha proferido esta frase, nem muito menos que as joias tenham sido vendidas, já que milhares de cearenses morreram de fome entre 1877 e 1889 (pelas contas mais conservadoras, cerca de $1 / 3$ da população da província).

Essa ambiguidade parece ter sido compreendida pelos camponeses, que, muitas vezes, agiam em nome do Rei, punindo os comissários locais ou tomando, eles mesmos, a liderança e a iniciativa na obtenção de gêneros e outros produtos de primeira necessidade. Creio poder afirmar que os conflitos ocorridos em Fortaleza, durante os anos de 1878-1880, possuem um nítido caráter de "justiça popular”, no qual os próprios camponeses-retirantes atacam comissários e comerciantes desonestos ou corruptos, que negociam com a miséria reinante na cidade e procuram beneficiar-se com a situação de caos. ${ }^{3}$

2 Narrativas de retirantes recolhidas por Leonardo Mota e publicadas no jornal A Lucta, de Sobral-CE (30.06.1915).

3 Convém lembrar que Fortaleza, neste período, recebeu uma população de retirantes estimada em 120.000 famintos, quando o censo de 1872 acusou uma população local de apenas 21.000. Pelos relatórios oficiais, cerca de 220.000 pessoas foram atendidas pelo sistema de socorros 
As "pagadorias" tornaram-se locais privilegiados da revolta popular, atraindo a ira dos trabalhadores nas obras públicas cujos salários miseráveis não eram pagos ou cujas rações de fome não eram distribuídas. Em 18/03/1878, por exemplo, a Praça Marques do Herval foi tomada por uma multidão de "pais de família", cujo pagamento diário não era realizado há três dias, e transformou-se em um palco de guerra. Os alvos principais dos amotinados eram os comissários encarregados pelo pagamento, acusados de desviar o dinheiro, enviado pelo governo imperial, em benefício próprio. Depois desse conflito, um prédio com paredes reforçadas é construído para receber a pagadoria em segurança, mas torna-se palco de um conflito ainda maior em 20/08/1878, quando cerca de 12.000 retirantes enfrentam soldados da polícia e da cavalaria. ${ }^{4}$ Nestes dois casos, o que se depreende é a imposição, pela ação coletiva das multidões, de uma forma de justiça popular baseada na compreensão dos camponeses sobre o destino das verbas destinadas pelo Imperador para amenizar a miséria dos pobres, em momento de crise extrema. O que estava em jogo, no limite, era um entendimento coletivo sobre a produção e o destino da riqueza social em momentos de crise, quando uma considerável parcela da população encontrava-se impossibilitada de garantir, por sua própria conta, o sustento. Se o avanço da economia de mercado alcançava, naqueles anos, a agricultura do algodão que se expandiu consideravelmente nos anos de 1865 1875 , a fome dos camponeses nos anos seguintes legitimava o retorno a certos padrões do paternalismo, de proteção aos pobres e distribuição de alimentos e roupas aos necessitados. O apelo ao Rei, que não deixaria morrer de fome seus "filhos", disseminava-se entre os retirantes, legitimando suas ações contra as autoridades, as quais, presas a uma ambiguidade de governo liberal que defende a não-intervenção estatal nos negócios de gêneros alimentícios mas se vê obrigado a atender àquela população desocupada e faminta, reagem com violência e "rara era a prisão effectuada pela cavalaria ou infantaria que não produzisse um assassinato". (Theophilo, 1922, p. 225)

Mas a interpretação popular, de baixo para cima, do "monarquismo ingênuo" produzia outros tipos de legitimação social. Os alimentos recolhidos em armazéns particulares ou em depósitos estatais deveriam, segundo a ótica popular, ser distribuídos gratuita e indiscriminadamente entre os pobres necessitados, mas eram estocados e vendidos, ou distribuídos quando estavam já estragados, beneficiando uma camada de intermediários comissionados pelo governo local. As irregularidades eram certamente notadas pelos retirantes, que perceberam também que somente a ação autônoma e direta poderia enfrentar a situação de desmantelo social e político. O roubo de alimentos, em armazéns públicos e privados ou em carroças que os distribuíam aos centros mais distantes, disseminavase por toda a província. Grupos de assaltantes se formaram nas estradas e, na cidade, os próprios carregadores usavam a "russega" (instrumento para retirar dos sacos amostras de grãos) para desviar grandes quantidades de gêneros para as famílias abarracadas na periferia. O roubo de grãos parecia seguir um padrão mais ou menos constante: os retirantes procuravam engajar-se em turmas de transporte, onde estariam 
mais próximos de situações em que a vigilância dos comissários e seus agentes era relaxada, e, assim, poderiam furtar o máximo possível de grãos com o mínimo possível de risco.

Rodolpho Theophilo, o farmacêutico, observou que "o furto se havia desenvolvido entre os retirantes de maneira incrível”, enquanto o Presidente da Província do Ceará, em 1879, José Júlio Barros, constatou serem “os analphabetos, os proletários, os homens carecidos de todos os benefícios da civilização que comettem a quasi totalidade dos crimes”. Não há dados precisos sobre o aumento dos furtos na capital durante esses anos, indicando um silêncio cúmplice que aponta os holofotes da opinião pública para os comissários corruptos e os comerciantes desonestos, isentando de responsabilidades os camponeses pobres afetados pela seca, incapacitados politicamente, no discurso público, pelo mito do camponês resignado e passivo. No entanto, quando presos, os retirantes revelavam o discurso oculto que inverte os padrões do paternalismo. Defendendo-se das acusações de roubo de grãos, afirmavam que "tudo era do Rei e por consequência lhes pertencia”. Esse argumento, associado à fome, reforçava o vínculo dos pobres com o Imperador, mas, em outro sentido, legitimava as ações populares que protagonizavam invasões e saques a mercados de alimentos. A lei que protege a propriedade estaria assim subordinada às normas culturais que demonizam o comerciante desonesto, que estoca alimentos ou os vende a preços mais altos em lugares afastados das comunidades originais, incluindo aqui o Estado que não distribui os gêneros que teriam sido enviados para satisfazer a necessidade urgente dos pobres. Desta forma, os próprios pobres percebem-se autorizados a ultrapassar a barreira da subordinação, organizando-se em pequenos grupos para atacar armazéns e outras instituições onde estavam estocados os alimentos. Não só a fome é saciada com os saques e roubos, mas também os camponeses impõem uma noção de justiça que criminaliza autoridades e comerciantes que negociam com a miséria do povo, em momentos de extrema necessidade, como é o caso das secas que destroem as fontes de sobrevivência das unidades produtivas baseadas na economia familiar. Na versão camponesa do "monarquismo ingênuo", por um lado, o Imperador não estava ciente das arbitrariedades cometidas em seu nome e, por outro lado, as propriedades reais poderiam ser apropriadas pelo povo na medida de sua necessidade. Se a monarquia não foi diretamente questionada pelas ações das multidões de camponeses, as formas hegemônicas de subordinação dos pobres a uma sociedade marcada pela desigualdade estrutural foram significativamente abaladas.

\section{O DISCURSO OCULTO DAS LIDERANÇAS}

José Ferreira de Melo era um carpinteiro, morador de Itapagé-CE, em 1951, quando foi preso sob a acusação de incitamento ao saque no mercado de alimentos. É apresentado no processo - que tem um tortuoso trajeto no interior do aparato judiciário - como um conhecido líder comunista que se aproveita da ingenuidade do povo camponês para satisfazer seus "intuitos políticos". ${ }^{5}$

5 Arquivo Público do Estado do Ceará (APEC), Ações criminais, pacote 40, nº 64, 1948-1953. O processo foi enviado, inicialmente, para a Justiça Militar, em razão do envolvimento de José com os comunistas. O promotor militar, contudo, o devolveu à Justiça Comum, alegando que nem a segurança nacional estava em risco, nem os militares haviam sido agredidos, embora entenda que "o fato, com efeito, merece severa reprimenda". 
O contexto é favorável a essas interpretações exageradas. A legalização do Partido Comunista do Brasil, em 1946, e sua atuação nos anos seguintes expunham a fragilidade da experiência democrática no país, depois do Estado Novo e da ditadura Vargas. Entre os magistrados e boa parte da intelectualidade brasileira, disseminava-se um sentimento de desconforto diante da presença ostensiva de comunistas organizando-se livremente e propagando suas doutrinas "subversivas" por todos os recantos do país. Particularmente, as propostas de reforma agrária, defendidas pelos comunistas, desagradavam às elites rurais que dominavam a cena política no semiárido nordestino, cujo apoio ao projeto estadonovista foi notório. A cassação do registro do partido, em 1947, porém, não significou o encerramento das atividades de seus militantes, que continuaram a organizar “células” partidárias em diferentes lugares, estimulando o movimento operário e popular. A repressão ao $\mathrm{PCB}$ representou, segundo Dulce Pandolfi, o alinhamento total do governo brasileiro com a política internacional comandada pelos Estados Unidos, no contexto da Guerra Fria (Pandolfi, 2014), autorizando funcionários e dirigentes estatais a combater e perseguir simpatizantes do "credo vermelho" por todas as áreas de sua atuação.

Por outro lado, a movimentação política dos próprios camponeses, nesses anos, assustou boa parte das elites agrárias brasileiras. A reunião, a ameaça, a invasão e o saque já haviam se tornado elementos positivos da cultura política dos camponeses do semiárido e, além disso, opções de luta disponíveis no interior de um arsenal político bastante reduzido no contexto da seca. Ao longo dos 70 anos anteriores, quando a seca se espraiava pelos sertões, num amplo processo de destruição generalizada da produção camponesa de subsistência, os retirantes aprenderam a negociar com os poderosos e com as autoridades de novas maneiras, articuladas com a cultura paternalista de relações diretas e pessoais, baseadas na vontade e força dos grandes proprietários de terras em troca de uma lealdade sempre instável e imprevisível por parte dos trabalhadores. O protesto direto - o saque, no limite - aparece neste contexto cultural como uma decisão radical, tomada em última instância, que transgride os códigos paternalistas de passividade e paciência, mas que, ao mesmo tempo, contraditoriamente pertence a esse mesmo universo de significados, forçando seus limites e ampliando as suas possibilidades. Pode-se dizer que uma tradição de ações da multidão ficou solidificada neste período, inspirando temor e respeito nas populações urbanas e nas autoridades locais, legitimando-se como possibilidade concreta de ação popular. Uma cultura de rebeldia tradicional se estabelece entre os camponeses do semiárido, alterando as bases de negociação política e as formas de organização do trabalho na região.

O protesto dos retirantes em Itapagé, portanto, não foi um ato isolado. Grupos de camponeses, desde o início de 1951, movimentavam-se por toda a região norte do Ceará, protagonizando conflitos em diversas cidades, à procura de proteção, apoio e comida. Em Pentecoste, Nova Russas, Coreaú, Canindé e, principalmente, Itapipoca, os revoltosos ameaçavam os mercados em busca de comida, pressionavam os canteiros de obras à procura de trabalho e invadiam prefeituras na intenção de obter apoio político. Multidões formadas por centenas e, às vezes, milhares de homens desesperados, chefes de famílias destruídas pela fo- 
me e pela vida nas estradas secas, ameaçavam a ordem hegemônica por meio da exposição pública de suas figuras esfarrapadas e por meio de atitudes que colocavam em prática aquela "estranha justiça com as próprias mãos". ${ }^{6}$

O grupo que invadiu a Prefeitura de Itapagé, em 12/05/1951, pretendia obter das autoridades alguma coisa para matar a fome e mais algumas promessas de trabalho para "atravessar" a seca. A novidade aqui, no entanto, é que parte do método de organização e pressão política passava pela carpintaria de José Ferreira de Melo. O discurso público, que infantiliza os camponeses, eleva a participação do comunista à situação de "liderança" e "manipulação", mas, em algum momento, cede lugar ao discurso oculto que permite perceber a colaboração entre camponeses rebelados e operários urbanos de esquerda. Ao ser interrogado, José alega que acompanhou o movimento "a convite de outros" e que estava em sua oficina de trabalho quando "compareceram cerca de vinte e cinco operários, gente oriunda de vários sítios desta comarca”. Os retirantes teriam alegado "que não sabiam expressar-se devidamente e queriam que o interrogado lhes servisse de interprete junto aquela autoridade”. O poder da palavra, assim, que normalmente é utilizado contra os camponeses pelos comerciantes, donos das terras e autoridades, poderia ser uma arma em favor das reivindicações dos retirantes, desde que expressa segundo os padrões convencionais. A fala articulada de José, muito provavelmente aprimorada na militância comunista, poderia significar um instrumento poderoso de negociação política, ao lado da mais tradicional forma de pressão: a multidão de famintos. Os camponeses rebelados pareciam saber disso e buscavam obter apoio de outros trabalhadores para sua causa.

A Prefeitura invadida por centenas de manifestantes tornou-se palco de discursos inflamados de trabalhadores que exigiam a distribuição de alimentos e a formação de turmas de trabalho para absorver os retirantes despojados de suas terras pela seca. José e outros oradores, como Edson Bastos Carneiro e outro trabalhador identificado apenas por Sá, revezavam-se na improvisada tribuna, ressaltando, de um lado, as necessidades das famílias de camponeses no momento dramático da seca e, de outro lado, a força coletiva da multidão de trabalhadores.

O discurso público dos camponeses passivos e incapazes, que precisam de apoio e proteção é de certa forma, reforçado pelos oradores populares, com a descrição de suas mazelas, suas doenças, suas famílias destruídas, suas terras ressecadas, sua fome e miséria. Contudo, ameaças mais ou menos veladas surgiam nos momentos em que se falava sobre o que poderia acontecer caso as reivindicações não fossem atendidas. Agora, reunidos em multidões, agregados em torno de um só objetivo, a força dos camponeses parecia irresistível e nada poderia lhes fazer frente. Os retirantes "sabem onde encontrar o que precisam" e podem fazer "justiça com as próprias mãos”. Essa argumentação, que oscila entre o discurso público e o discurso oculto, é dirigida principalmente para as autoridades, deixando-as perceber que os camponeses podem se comportar como está prescrito na ordem hegemônica ou podem se rebe-

6 Reportagem de Paulo Bonavides, em O Povo, 23.05.1951. Para um mapeamento dessas ações neste período, ver inúmeras edições de O Povo e O Democrata entre 1951 e 1953. 
lar violentamente, dependendo das respostas a suas demandas. O que pode resultar dessa violência é imprevisível. O que se vislumbra, desse argumento, é que os subordinados comunicamse entre si e alimentam sentimentos de rancor e vingança, que podem se desdobrar em atitudes transgressoras, segundo a ótica dominante. Aquilo que parece oculto pelas barreiras da dominação social, num relance, aparece como possibilidade real, aterrorizando aqueles encarregados de defender a manutenção dos valores hegemônicos. As leis que regem a propriedade e a ordem social poderiam ser ultrapassadas de tal forma que as autoridades preferem negociar.

O Prefeito de Itapagé prometeu conseguir trabalho para os retirantes em obras de construção de açudes nas cidades circunvizinhas e a multidão se dispersa, depois da distribuição de cestas de alimentos, resultado da mobilização imediata dos comerciantes ameaçados, e de um alistamento de trabalhadores aptos a ingressar imediatamente no canteiro de obras. A prisão de José Ferreira de Melo foi uma tentativa grotesca de combater o perigo comunista na cidade, processo que, ao final, com a recusa da Justiça Militar, resultou em sua absolvição.

Se os eventos de Itapagé não chegaram a se constituir em uma "declaração pública do discurso oculto", permitem, num vislumbre, perceber a "infrapolítica" dos pobres, que "é essencialmente a forma estratégica que a resistência dos subordinados deve assumir em condições de grande perigo". (Scott, 2013, p. 273)

\section{A UTOPIA DOS POBRES}

Uma das mais importantes e destacadas linhas de argumentação do discurso público sobre os pobres é que eles não conseguem, por motivos diversos, articular um projeto consistente de formação de uma sociedade alternativa, em oposição à ordem hegemônica que os oprime. A formulação de um projeto social racional e sistemático parece escapar da consciência dos pobres pelas condições de necessidade em que vivem, absorvidos pela busca da sobrevivência imediata.

A politização das ações das multidões parece sempre uma atribuição exterior, operada por algum agente externo com o qual a multidão se relaciona, seja uma organização popular (sindicatos ou partidos), seja uma instituição estatal ou um evento da vida representativa (uma eleição ou uma disputa entre potentados locais). A dificuldade em qualificar politicamente os camponeses possui origens e significados diversos, com os quais eu mesmo procurei dialogar em outros momentos. (Neves, 2000, p. 9-20) 7 De modo geral, contudo, essa dificuldade parece estar relacionada à definição do próprio conceito de política, com o qual as diversas forças sociais procuram entender as relações de poder e as formas e manifestações das vontades coletivas.

Em primeiro lugar, esse conceito identifica-se e possui significado no interior do campo de atuação do Estado, que define não só o

\footnotetext{
7 O debate sobre ações "sub" ou "pré" políticas teve importância crucial nas pesquisas desenvolvidas por historiadores sociais ingleses, especialmente nas décadas de 1950 e 1960. Os trabalhos seminais de Thompson (1987, v. 1) e principalmente Hobsbawm (1978) foram definitivamente superados, no que diz respeito a essa questão, pelas investigações de George Rudé (1991) e do próprio Thompson (1998, p. 150-199). O conceito de "economia moral", segundo este historiador inglês, parece articular melhor os elementos envolvidos nas ações dos populares e, assim, explicar melhor suas motivações políticas. Cf. também Neves (1998). Em entrevista concedida no final dos anos de 1980, Hobsbawm relembra esse debate e revê suas posições a respeito.
} 
grau de "politização" das ações sociais quanto sua eficácia. Assim, grosso modo, as ações políticas seriam aquelas que se dirigem (contra ou a favor) aos organismos estatais, cujas demandas se originam nas possibilidades de satisfação pelas características de organização dos grupos no comando do Estado, e/ou se organizam nos moldes estabelecidos pela política representativa moderna. O modelo hierárquico de estruturação das instituições ditas modernas (partidos, sindicatos, associações de classe), baseado na rígida separação entre dirigentes e executantes, torna-se o referencial básico para a identificação de formas políticas de organização e direcionamento das ações coletivas. ${ }^{8}$ É necessário, para esse entendimento, a clara percepção de lideranças cujo papel é fundamental para diferenciar os grupos coletivos “organizados” das "hordas" sem objetivo definido; por outro lado, os líderes podem ser responsabilizados judicialmente pelos resultados dessas ações que não correspondam aos parâmetros da legalidade instituída. Somente as formas de organização popular, portanto, que correspondam a esse modelo estabelecido (que provém da política representativa liberal) são reconhecidas como políticas e encontram canais de diálogo mutuamente identificáveis, tanto pelas organizações operárias modernas (partidos, sindicatos etc), quanto pelas instituições estatais (prefeituras, órgãos públicos etc). ${ }^{9}$ A Política, desta forma, fica circunscrita a um campo definido pe- lo Estado e seus padrões estruturais, estabelecido como "civilizado", relegando a diversidade de formas populares de organização e defesa de seus direitos ou costumes ao campo da "bárbarie" - ações auto-indulgentes, desprovidas de sentido coletivo e de parâmetros de convivência social, segundo regras de troca equivalente baseadas no mercado. É preciso questionar continuamente, portanto, a "severidade da história que há muito tem sido cativa do Estadonação, que em muitos estudos continua sendo a moldura de análise largamente incontroversa”. (Linebaugh e Radiker, 2008, p. 15)

Em segundo lugar, a política se define como uma atividade racional, em que os fins são estabelecidos em função de objetivos traçados previamente - uma "ação racional-com-respeito-a-fins", segundo critérios weberianos. ${ }^{10}$ O reconhecimento de uma ação como política pressupõe, nessa perspectiva, o reconhecimento prévio de um programa geral, no qual essa ação particular se insere. Desta forma, uma conexão direta se estabelece entre a ação particular e o programa do qual deriva, fazendo com que seus significados sejam definidos nesta relação, de pensamento e ação, de consciência/ vontade e consecução de um plano. Fora destes parâmetros racionais, a ação é destituída de sentido, presa a um campo da satisfação animal dos desejos ou necessidades. A fome, portanto, parece ser a representação ideal desta mani-

8 Cf. Castoriadis (1985, p. 11-78). A eficácia das ações políticas assim compreendidas corresponde à eficiência e produtividade da produção em massa operada pela indústria, de onde o modelo deriva.

9 Os partidos de esquerda encontram grande dificuldade em reconhecer nas ações das multidões de retirantes um conteúdo político a ser apoiado ou mesmo reconhecido como parceiro de lutas. Com exceção de uma "conferência de flagelados" organizada pelo PCB em 1953 (O Democrata, 19, 22 e 23.12.1953), somente em 1982 entidades ligadas à Teologia da Libertação, uma facção da Igreja Católica, inauguram o apoio efetivo de organizações populares a movimentos de invasões ou saques. Cf. Neve (1994).

10 Cf. Habermas (1975). A própria ideia de "racionalidade" ficaria assim restrita, segundo Habermas, ao estabelecimento de relações diretas entre meios e fins. 
festação irracional de revolta, quando homens desesperados transgridem valores sociais básicos e ultrapassam a barreira do relacionamento dito "civilizado", cometendo violências contra a propriedade ou ameaçando diretamente as pessoas. E. P. Thompson resumiu este tipo de compreensão sobre essas ações das multidões (no caso de sua pesquisa, os motins da fome da Inglaterra do século XVIII) como "visão espasmódica". (Thompson, 1998, p. 200250) Segundo ele, a fome não prescreve a ocorrência da ação, embora seja inevitavelmente um de seus elementos legitimadores. A ação ocorre no interior de um sistema de valores, expectativas e comportamentos que lhe confere sentido e, em contextos específicos, legitimidade social. Os motins estavam conectados a um momento de escassez ou de alta de preços dos produtos básicos, como o pão, e suas formas de organização e transmissão de informações se ligavam e se difundiam através da oralidade e de outras maneiras tradicionais de articulação social. Procurei demonstrar que, no caso das ações dos retirantes, as secas fornecem esse elemento legitimador, que impede ou neutraliza a repressão. A ausência de uma "direção responsável" pelo movimento parece, de um lado, dificultar a negociação, pela inexistência de canais institucionais de diálogo e, de outro, neutralizar o seu potencial transgressor ou destrutivo. Assim, sem um plano geral ou um projeto de sociedade que a qualifique, a ação das multidões famintas é relegada ao campo dos instintos e da animalidade, explicada muitas vezes por teorias tributárias de uma "psicologia das multidões", no estilo de Le Bon, Sighelle ou Tarde. Assim, pode ser tolerada pela sociedade moderna, indiferente frente aos dilemas arcaicos de camponeses arruinados.
Porém, como nos ensinou Koselleck (2006, p. 312-313), não há experiência sem expectativa Mais uma vez, relegado ao discurso oculto, o programa político defendido pelos camponeses não aparece no discurso público. Primitivas, instintivas, espontâneas, explosivas, as ações das multidões de camponeses arruinados parecem não ter um fim, um "horizonte de expectativa", uma concepção implícita e diretiva do que seria uma sociedade boa, organizada segundo um padrão que os satisfizesse individual e/ou coletivamente.

Observando essas ações, sua amplitude no espaço e no tempo, sua eficácia específica, sua frequência, sua presença no imaginário coletivo, suas formas de reproduzir-se na arte e na literatura, creio ser possível afirmar, ao contrário, que elas possuem um significado histórico, uma projeção para além do imediato, que por certo se baseia nas experiências passadas, mas se articula, a partir de alguns elementos gerais, como proposta de mudança social. O que pensam os camponeses sobre uma sociedade ideal? Que projeto os move em suas ações? Como seria essa utopia dos pobres?

As respostas a essas perguntas não são simples e só podemos inferi-las por meio das próprias ações dos camponeses insurretos, tentando perceber nelas uma estrutura de sentidos. Analisando-as, podemos deduzir, em linhas bem gerais, que sonhos utópicos seriam capazes de fazê-los romper as barreiras da submissão e do discurso público.

As ações das multidões de camponeses arruinados ocorrem em momentos específicos de crise social - a seca - do qual retiram legitimidade e adesão da população. A generalização da miséria e a fome configuram um am- 
biente cultural que suspende as normas comuns do mercado e da organização da produção. Se, no ritmo normal da produção, os camponeses aceitam algumas mudanças nas formas de produção (desde que não alterem fundamentalmente o controle sobre o tempo), nos momentos de crise eles procuram retomar valores quase perdidos pelo progresso das relações de mercado. Assim, as normas do paternalismo rural, baseadas na reciprocidade desigual e na troca de deferência por proteção, são reativadas para fornecer aos miseráveis uma alternativa de sobrevivência nos momentos em que as normas comuns do mercado não lhes permitem a reprodução de suas condições sociais. Há, portanto, uma seleção dos elementos da tradição paternalista que podem corresponder às necessidades atuais dos pobres, que procuram se proteger da fome através de mecanismos tradicionais de proteção pessoal. Trata-se de um aprendizado dramático, que as primeiras gerações de camponeses reunidos em multidões sofreram para absorver.

O avanço das relações baseadas no mercado ocorreu maciçamente, no semiárido nordestino, na metade do século XIX, exatamente em um período de regularidade climática, entre 1845 e 1877 . Os fluxos migratórios locais, através dos quais os camponeses se resguardavam da miséria em tempos de falta de chuvas, foram fechados. Ao mesmo tempo, os proprietários endividavam-se na "febre" da produção do algodão e, em seu declínio, no começo da década de 1870, encontravam-se empenhados em resguardar suas propriedades e seus capitais diante das cobranças dos bancos e das empresas de exportação. A seca de 1877 , portanto, acontece em momento vital nas relações entre os camponeses e os donos de terras, destruindo as alternativas tradicionais para a resolução da ausência de chuvas e obrigando os camponeses a migrar maciçamente para as cidades. Os proprietários, nesse contexto de crise, transferem para o Estado suas responsabilidades tradicionais de proteção aos pobres. Desta forma, a capital do Ceará, Fortaleza, transforma-se no alvo primordial da migração de camponeses arruinados, posto que abrigava a sede do poder, onde se poderia conseguir a proteção devida. (Neves, 2000)

Os camponeses fazem uma leitura desse contexto na qual a proteção tradicional aos pobres, devida pelos poderosos, não poderia ser negada. Se os donos de terras não podem fazê -lo, caberia ao Estado (ou os "poderosos") assumir essa responsabilidade. Ao fazer essa leitura do momento, os camponeses precisavam aprender a lutar por essa ideia.

De um lado, precisavam saber o momento exato para deixar os campos ressecados. Isso era (e ainda, de certa forma, é) um problema delicado, já que, no século XIX, as estradas precárias transformavam-se em verdadeiros cemitérios a céu aberto, como relatam os cronistas. Era preciso uma reserva de energia e comida para a retirada e a chegada a uma cidade estranha, onde os caminhos da ajuda eram incertos. A partir de 1915, as estradas de ferro vieram facilitar esse trajeto, fazendo com que os observadores de dividissem no entendimento dessa antecipação da invasão dos retirantes: uns entenderam que os primeiros a chegar na capital formavam uma "gente ruim (...) vagabunda por instinto e preguiçosa por índole", que "saindo não faz falta" (Teófilo, 1982, p. 37-38); outros perceberam que eram os arrendatários, que não tinham propriedades a de- 
fender ou preservar, os que chegavam antes. A política de assistência empreendida pelo governo obedecia a essa discriminação e, para os arrendatários e posseiros, prevaleciam as migrações incentivadas para a Amazônia ou para o sul do país, enquanto que, para os pequenos proprietários arruinados, eram criados programas de trabalho para que pudessem permanecer no estado, recebendo um "salário", e retornar às suas terras o mais rapidamente possível. Sobre estes, "geralmente dos que possuíam terras no interior", o governo entendia que se devia evitar o seu "prejudicial expatriamento". ${ }^{11}$

De outro lado, as armas políticas a serem empregadas nesse novo momento não poderiam ser as mesmas do personalismo que caracteriza o paternalismo rural, embora não pudessem se distanciar completamente desse modelo. As "lutas por direitos" ainda não estavam disponíveis para esses trabalhadores nesse momento de passagem do século XIX para o século XX (em 1951, o episódio envolvendo José Ferreira de Melo e sua prisão, em Itapagé, corresponde a um momento em que essa alternativa já está colocada e os camponeses procuram inseri-la em seu arsenal de armas políticas). Assim, a multidão e suas formas de pressão coletiva e direta aparecem como uma novidade política em 1877 e se consolidam ao longo dos cem anos seguintes, pelo menos. ${ }^{12}$ Ao longo desse processo, alcançam uma legitimidade social que ameniza e, às vezes, impede a repressão por parte das autoridades e das milícias particu- lares. Se, nos primeiros anos pós-1877, os conflitos ganhavam dimensões gigantescas na cidade - com a mobilização de forças policiais armadas para conter as multidões de retirantes e a ação de grupos de assassinos que executavam ou puniam os camponeses revoltosos nas fazendas -, nos anos posteriores, a repressão oficial foi se resumindo a proteger as propriedades ou organizar filas de alistamentos. Poucos são presos e raros são processados. Os assassinatos de líderes rurais não diminuem, mas raramente se associam a movimentos de invasões ou saques.

Desta forma, a eficácia das ações das multidões, para além de seus objetivos imediatos de saciar a fome de seus participantes, consiste em colocar limites para a expansão da economia de mercado nos momentos de escassez e crise. Com isso, os camponeses elaboram uma proposta implícita de distribuição da riqueza social que contempla a proteção aos mais pobres em momentos difíceis e a garantia de controle do tempo de trabalho pelos camponeses. Não é pouca coisa. Trata-se da utopia que oscila entre um governo bondoso, que atenda aos anseios dos pobres, e uma terra de pequenos proprietários, que não necessitam de governo nenhum. De qualquer maneira, o programa contempla a manutenção da autonomia camponesa sobre os meios de produção e o tempo de trabalho, assim como, de outro lado, a desvinculação e o descomprometimento dos pobres para com a administração dos negócios públicos e a gestão do Estado. A posição contraditória dos

11 Relatório do Presidente do Estado do Ceará, Coronel Benjamim Barroso, à Assembleia Estadual, em 1916.

12 A seca atual (2013), embora seja apresentada pelos especialistas como uma das maiores do século, em termos de abrangência espacial e irregularidade pluviométrica, não se desdobrou em números significativos de ações da multidão. Talvez (ressalto o 'talvez'), as medidas assistencialistas empreendidas pelo governo federal depois de 2002 (Bolsa Escola, Bolsa Família, Seguro Safra, além da aposentadoria rural, entre outras) tenham feito com que os camponeses, apesar da destruição das colheitas, tenham preferido permanecer em suas localidades, sobrevivendo à custa desses benefícios. 
camponeses no sistema de subordinação estrutural em que vivem faz com que elaborem um programa igualmente contraditório, oscilando entre a autonomia total e a subordinação parcial, entre uma vida comunitária independente e a heteronomia condicional.

Tanto num caso como no outro, portanto, afirma-se uma barreira ao processo de apropriação (rendas, tributos ou obrigações) que, mesmo quando não apresenta um questionamento radical ao processo de subordinação, possui eficácia histórica quanto ao estabelecimento de obstáculos à expansão da economia de mercado no semiárido.

O protagonismo dos camponeses reafirma valores comunitários, supervaloriza a autonomia do pequeno produtor e atrasa o "progresso", isto é, o desenvolvimento das formas capitalistas de produzir e organizar a vida social. Em nome da tradição, combatem as normas econômicas centradas no mercado; em nome da vida, enfrentam as barreiras seculares da subordinação política e social.

Trabalho recebido em 25/05/2013 Aprovado para publicação em 10/08/2013

\section{REFERÊNCIAS BIBLIOGRÁFICAS}

CASTORIADIS, C. A Experiência do Movimento Operário. São Paulo: Brasiliense, 1985.

HABERMAS, J. Ciência e Técnica como "Ideologia”. In: Os Pensadores. Vol. XLVIII. São Paulo: Abril, 1975, p.303-333.
HOBSBAWM, E. J. "Entrevista com Eric Hobsbawm." Estudos Históricos. Rio de Janeiro: CPDOC-FGV, v. 6, nº 20, p. 42-55, nov/1990.

HOBSBAWM, E. J. Rebeldes Primitivos: estudos sobre formas arcaicas de movimentos sociais nos séculos XIX e XX. 2 ed. Rio de Janeiro: Zahar, 1978.

KOSELLECK, R. Futuro Passado: Contribuição à semântica dos tempos históricos. Rio de Janeiro: Contraponto/PUC-Rio, 2006.

LINEBAUGH, P. e RADIKER, M. A Hidra de Muitas Cabeças: marinheiros, escravos, plebeus e a história oculta do Atlântico revolucionário. São Paulo: Companhia das Letras, 2008.

NEVES, Frederico de C. "Economia Moral versus Moral Econômica: o que é economicamente correto para os pobres?" Projeto História. São Paulo: Educ, no 16, p. 39-57, 1998.

NEVES, Frederico de C. "Estranhos na Belle Époque: a multidão como sujeito político (1877-1915)." Trajetos. Fortaleza: n. 6, p.113138, 2005.

NEVES, Frederico de C. A Multidão e a História: saques e outras ações de massas no Ceará. Rio de Janeiro: Relume Dumará, 2000.

NEVES, Frederico de C. Imagens do Nordeste: a construção da memória regional. Fortaleza: SECULT-CE, 1994.

PANDOLFI, Dulce. Entre dois governos: 19451950 > A cassação do Partido Comunista no cenário da Guerra Fria. http://cpdoc.fgv.br/producao/dossies/AEraVargas2/artigos/DoisGovernos/CassacaoPC. Acesso em 25.01.2014. 
RUDÉ, G. A Multidão na História: estudo dos movimentos populares na França e na Inglaterra, 1730-1848. Rio de Janeiro: Campus, 1991.

SCOTT, J. C. A Dominação e a Arte da Resistência: Discursos Ocultos. Lisboa: Livraria Letra Livre, 2013.

TEÓFILO, R. A Seca de 1915. 2 ed. Fortaleza: Ed. UFC, 1982

THEOPHILO, Rodolpho. História da Secca do Ceará (1877-1880). Rio de Janeiro: Imprensa Inglesa, 1922.

THOMPSON, E. P. A Formação da Classe Operária Inglesa. Rio de Janeiro: Paz e Terra, 1987.

THOMPSON, E. P. Costumes em Comum: estudos sobre a cultura tradicional. São Paulo: Companhia das Letras, 1998.

THOMPSON, E. P. Folclore, Antropologia e História Social. In: A Peculiaridade dos Ingleses e Outros Ensaios. Campinas: Ed. UNICAMP, 2001. 